\title{
A comparative study of specific gene probes and standard bioassays to identify diarrhoeagenic Escherichia coli in paediatric patients with diarrhoea in Bangladesh
}

\author{
S. M. FARUQUE, K. HAIDER, M. J. ALBERT, Q. S. AHMAD, A. N. ALAM, \\ S. NAHAR and S. TZIPORI
}

Laboratory Sciences Division, International Centre for Diarrhoeal Disease Research, GPO Box 128, Dhaka 1000, Bangladesh

\begin{abstract}
Summary. We compared the usefulness of gene probes with standard bioassays to identify diarrhoeagenic Escherichia coli amongst isolates from Bangladeshi children under 1 year of age with diarrhoea. $E$. coli isolates were analysed with specific gene probes for localised adhesiveness (LA), diffuse adhesiveness (DA), heat-labile toxin (LT), heat-stable toxin (ST), Shiga-like toxins (SLT I and SLT II), and enteroinvasiveness, and in bioassays for production of enterotoxins and cytotoxins, and for cell adherence. With 1136 isolates from 387 patients, there was general agreement between the two assay methods. When there was disparity, gene-probe-positive isolates gave negative results in the corresponding bioassay. In the HeLa cell adherence assay, $94 \%$ of the LA probe-positive isolates and $91.6 \%$ of the DA probepositive isolates gave positive bioassay results for LA and DA respectively. Thirty-six of 39 LT probe-positive isolates and 73 of $86 \mathrm{ST}$ probe-positive isolates gave positive results in the bioassays. Of 28 isolates that gave negative results in the suckling mouse assay but were initially positive with the probe for ST, 15 were later found to hybridise with the cloning vector for the ST probe. Addition of denatured vector DNA at a concentration of $10 \mu \mathrm{g} / \mathrm{ml}$ in the hybridisation solution eliminated these false positive results. None of the other probepositive isolates hybridised with any of the cloning vectors used. The DNA hybridisation assay appeared to be a convenient alternative to bioassays for screening large numbers of isolates in epidemiological investigation.
\end{abstract}

\section{Introduction}

Diarrhoeagenic categories of Escherichia colienterotoxigenic (ETEC), enteropathogenic (EPEC), enterohaemorrhagic (EHEC), and enteroinvasive (EIEC) - are a major cause of diarrhoea in infants and young children in developing countries and a leading cause of travellers' diarrhoea and haemorrhagic colitis in developed countries. ${ }^{1-3}$ These $E$. coli strains produce one or more enterotoxins, cytotoxins, colonisation factors and adhesins, which contribute to the development of diarrhoea. ${ }^{1} E$. coli strains that produce toxins or adhesins, or both, are usually identified in bioassays with live animals ${ }^{4}$ or cultured cells $s^{5-8}$ or in immunoassays $^{9,10}$ that require specific antisera. Because these techniques are time-consuming, expensive and not suitable for screening large number of isolates, recombinant DNA technology has been used.

Nucleotide probes have been developed to identify plasmid encoded genes for heat-labile (LT) and heatstable (ST) enterotoxins, ${ }^{11}$ genes involved in enteroinvasion, ${ }^{12}$ bacteriophage-encoded genes for Shiga-

Received 3 Oct. 1990; revised version accepted 4 April 1991. like toxins (SLT I and SLT II), ${ }^{13}$ and genes involved in localised (LA), diffuse (DA), and aggregative (AggA) adherence ${ }^{14-17}$ In initial studies, these probes have provided encouraging results in detecting diarrhoeagenic $E$. coli strains. ${ }^{11-15,17,18}$ However, there have not been any studies in which large numbers of clinical isolates have been tested simultaneously with a wide variety of gene probes and bioassays in a single investigation. The present study was done to assess the general usefulness of a wide range of gene probes in identifying diarrhoeagenic $E$. coli in the stools of children with diarrhoea to compare the results with those of standard bioassays, and to investigate the relative importance of the various categories of $E$. coli as causes of early childhood diarrhoea in Bangladesh.

\section{Materials and methods}

The Clinical Research Centre of the International Centre for Diarrhoeal Disease Research, Bangladesh (ICDDR,B) has a surveillance system in which every 25 th patient seen is entered into the programme for in-depth clinical, microbiological and demographic 
investigation. ${ }^{19}$ Between March and August of 1988 , stools were obtained from 387 children up to 1 year of age with diarrhoea. The stools were cultured ${ }^{19}$ and three $E$. coli isolates from each stool were stored on nutrient-agar slants for further analysis.

\section{DNA hybridisation assays}

DNA probes were prepared from recombinant plasmids containing the probe DNA fragments as inserts. Plasmids were prepared, purified, and digested with restriction endonucleases (Bethesda Research Laboratories, Gaithersburg, MD, USA) and the appropriate restriction fragments were purified as described by Moseley et al. ${ }^{11}$ The ST probes consisted of a 216-bp EcoRI digestion fragment of plasmid pCVD402 derived from the cloned STh gene ${ }^{20}$ and a 157-bp PstI fragment of plasmid pCVD404 derived from the cloned STp gene. ${ }^{21}$ The recombinant plasmids pCVD402 and pCVD404 were constructed at the Centre for Vaccine Development (Baltimore, MD, USA) by cloning the DNA fragments into the vector plasmid pBR325. The origin and construction of the other gene probes have been described previously. ${ }^{11-}$ 15,22 The LT probe was a 1-3-kb BamHI digestion fragment of plasmid pCVD403. ${ }^{11,22}$ The SLT I probe was a 1-1-kb BamHI fragment of plasmid pJN37-19 and the SLT II probe was a SmaI-Pst I 850-bp digestion fragment of plasmid pNN110-18. ${ }^{13}$ The LA probe was a l-kb Bam HI-Sall fragment of plasmid pJPN16, derived from plasmid pMAR2, ${ }^{14}$ the DA probe was a $P_{\text {st I }}$ 450-bp fragment of plasmid pSLM852, ${ }^{15,16}$ and the EIEC DNA probe was a 17-kb EcoRI digestion fragment of plasmid pRM17. ${ }^{12}$

DNA fragments were labelled by random priming ${ }^{23}$ with $\left[\alpha^{-32} \mathrm{P}\right]$-deoxycytidine triphosphate $(3000 \mathrm{Ci} /$ mmol, Amersham International plc, UK) and a random primers DNA labelling kit (BRL). Colony blots were prepared, processed and hybridised under stringent conditions as described by Echeverria $e t$ al. $^{24}$
All probe-positive isolates were screened for false positive results by hybridising with the corresponding vector DNA. Purified plasmids (either obtained from BRL or prepared in our laboratory) were labelled by nick translation ${ }^{25}$ and hybridised with the colony blots. These isolates were also hybridised for a second time with the corresponding radiolabelled probe DNA; the hybridisation solution was supplemented with $10 \mu \mathrm{g} / \mathrm{ml}$ of the corresponding unlabelled denatured vector DNA.

\section{Bioassays for toxin production and adherence}

All $E$. coli strains were tested for enterotoxin production by the suckling mouse assay for $\mathrm{ST}^{4}$ and by the Y1 adrenal cell assay for LT. ${ }^{5}$ Production of cytotoxins was tested in the Vero cell assay. ${ }^{6}$ Strains were assayed for their patterns of adherence to tissueculture cells as described by Cravioto et al. ${ }^{7}$ Instead of HEp- 2 cells, HeLa cells were used $^{8}$ and the adhesion test was incubated for $3 \mathrm{~h}$ in the presence of methyl$\alpha$-D-mannoside $1 \%$. Three distinct patterns of adherence, as defined by Nataro et al. ${ }^{26}$ were assessed and the opinions of two independent observers were considered.

\section{Results}

Of 1161 isolates stored for examination, 25 could not be revived; tests were done on 1136 isolates representing all 387 patients. In DNA probe analysis, $3.4 \%$ gave positive results for $\mathrm{LT}, 7.5 \%$ gave positive results for $\mathrm{ST}$, and $3.0 \%$ gave positive results for both LT and ST; $11.8 \%$ gave positive results for LA and $6.3 \%$ for DA (table). None of these isolates gave positive results with the probes for enteroinvasiveness or for SLTs and were not tested for invasiveness in a bioassay.

The subsequent bioassay of probe-positive isolates showed that some $(5 \cdot 9-15 \cdot 1 \%)$ isolates which gave positive results with a DNA probe gave negative

Table. Comparison of DNA hybridisation with standard bioassays for the detection of diarrhoeagenic $E$. coli in 1136 isolates from 387 children up to one year old with diarrhoea

\begin{tabular}{l|cccc}
\hline & \multicolumn{4}{|c}{ Number of isolates that were } \\
\cline { 2 - 5 } $\begin{array}{l}\text { Toxins and } \\
\text { adhesins }\end{array}$ & $\begin{array}{c}\text { Probe and } \\
\text { bioassay } \\
\text { positive }\end{array}$ & $\begin{array}{c}\text { Probe positive, } \\
\text { bioassay } \\
\text { negative }\end{array}$ & $\begin{array}{c}\text { Total } \\
\text { probe } \\
\text { positive }(\%)\end{array}$ & $\begin{array}{c}\text { Total } \\
\text { bioassay } \\
\text { positive }(\%)\end{array}$ \\
\hline LT & 36 & 3 & $39(3 \cdot 4)$ & $36(3 \cdot 1)$ \\
ST & 73 & 13 & $86(7 \cdot 5)$ & $73(6 \cdot 4)$ \\
LT+ST & 29 & $6^{*}$ & $35(3 \cdot 0)$ & $29(2 \cdot 5)$ \\
LA & 127 & 8 & $135(11 \cdot 8)$ & $127(11 \cdot 1)$ \\
DA & 66 & 6 & $72(6 \cdot 3)$ & $66(5 \cdot 8)$ \\
AggA & $\ldots$ & $\ldots$ & ND & $59(5 \cdot 1)$ \\
\hline
\end{tabular}

ND, not done.

* Of the 29 isolates that were both LT- and ST-positive in the DNA probe assay, six produced only LT in the bioassay. 
results in the corresponding bioassay. Thirty-six $(92.3 \%)$ of the 39 LT-positive isolates from 23 of the 25 patients with LT-positive $E$. coli produced an active toxin detected in the bioassay. Seventy-three $(84.8 \%)$ of 86 ST-positive isolates, obtained from 38 of 44 patients with ST-positive $E$. coli, gave positive results in the bioassay for ST. Of the enterotoxigenic isolates that gave positive results for both LT and ST by DNA hybridisation, $29(82.8 \%)$ of 35 isolates from 12 of the 15 patients with $\mathbf{L T}+\mathrm{ST}$-positive $E$. coli, gave positive results for both toxins in the bioassay. The remaining $17 \cdot 2 \%$ (six isolates from three patients) produced only LT in the bioassay (table). In the HeLa cell adherence assay, $94 \%$ of the LA probe-positive isolates (127 of 135 isolates from 69 of 72 patients) and $91.6 \%$ of the DA probe-positive isolates ( 66 of 72 isolates from 45 of 47 patients) gave positive results for LA and DA respectively. Fifty-nine (5.1\%) isolates from 25 patients showed the AggA pattern. It was sometimes difficult to distinguish between the different adherence patterns. With 20 isolates, the opinion of two independent observers differed in the first instance, and the assay was repeated.

Initially, 28 isolates that gave' negative results for ST in the bioassay gave positive results in the DNA hybridisation assay. However, 15 of these isolates hybridised with purified plasmid pBR325 DNA, the cloning vector for the ST probes. The second round of hybridisation of the 15 isolates (which hybridised with pBR325 DNA) with the ST probe in the presence of denatured unlabelled pBR325 DNA showed no hybridisation, leaving 13 probe-positive but bioassaynegative isolates (table). These 13 isolates came from six patients. All probe-negative isolates also gave negative results in the bioassays. None of the other probe-positive isolates hybridised with the corresponding cloning vectors.

\section{Discussion}

Three of 39 LT probe-positive and 13 of 86 STprobe positive isolates gave negative results in bioassays (table). Of 29 isolates that gave positive results with both the LT and ST probes, six produced only LT in the bioassay. Another 15 isolates that hybridised with the ST probe but were bioassay negative were shown to be false positive, because they hybridised with the cloning vector. This could be due to the presence of vector DNA contaminating the probe. A similar problem has been described previously. ${ }^{18}$ The reason why the remaining $13 \mathrm{ST}$ probe-positive isolates from six patients and three LT probe-positive isolates from two patients did not produce an active toxin in the bioassay is not clear. Possible explanations could be a lack of optimum expression of the toxin genes under the growth conditions or deletion of small regions of the LT or ST gene resulting in impairment of expression. The possible presence of cryptic sequences homologous to the LT or ST gene (unable to produce an active toxin) in certain isolates may also contribute to this higher detection rate of ETEC by DNA hybridisation assay than in the bioassays. This level of disagreement between probe assay and suckling mouse assay for ST has been reported previously. ${ }^{27}$ The finding that six isolates that gave positive results for both LT and ST in the probe assay gave positive results only for LT in the bioassay (table) indicated that expression of the LT and ST genes is independent of each other and that the absence of expression in one of these genes does not affect the expression of the other gene.

All probe-negative isolates also gave negative results in the bioassays; this indicated that the presence of DNA sequences homologous to the probe DNA in these isolates was consistent with the expression of the respective pathogenic trait. This also excluded the possibility of any high degree of genetic heterogeneity in these isolates for the expression of these toxins and adhesins. Furthermore, a negative result in the DNA hybridisation assay appeared to be more accurate than a positive result.

In agreement with a recent report, ${ }^{14}$ strains that gave positive results with the LA probe also gave positive bioassay results (with the exception of eight strains out of 135). Although the role of DA E. coli in the pathogenesis of diarrhoea is controversial, ${ }^{26,27}$ both the DNA probe assay and the HeLa cell adherence assay detected a significant number of DApositive isolates and the two assay methods generally agreed. The reasons why eight LA probe-positive isolates (from three patients) and six DA probepositive isolates (from two patients) gave negative results in the bioassays could be similar to those suggested for the enterotoxigenic isolates. Fifty-nine isolates showed the AggA pattern but it was sometimes difficult to distinguish between the true DA and AggA patterns. These AggA isolates need to be tested with the DNA probe for enteroaggregative $E$. coli $^{17}$

Because the HeLa cell adherence assay relies on observation of different patterns of adherence by microscopic examination, there is a considerable chance that an inexperienced observer may incorrectly identify the adherence pattern. The DNA hybridisation assay is usually free of such qualitative interpretation. There was, however, a problem of false positive results in this study with the plasmid-based DNA probe for ST, which was eliminated by supplementing the hybridisation solution with unlabelled denatured vector DNA.

From a practical point of view, bioassays are useful in obtaining rapid results while analysing a small number of isolates. There are different opinions regarding the sensitivity and specificity of the DNA hybridisation assay, ${ }^{11,18}$ but the major advantages of the assay are that a large number of isolates can be analysed quickly and it is more cost-effective than bioassays. Therefore, DNA probes are more useful than bioassays in screening large number of isolates in epidemiological investigations. 
This research was supported by the United States Agency for International Development (USAID) and the International Centre for Diarrhoeal Disease Research, Bangladesh (ICDDR,B); ICDDR,B is supported by The Aga Khan Foundation, Arab Gulf Fund, Australia, Bangladesh, Belgium, Canadian International Development Agency (CIDA), Canadian International Development Research Centre (IDRC), Danish International Development Agency (DANIDA), France, the Ford Foundation, Japan, the Netherlands, Norwegian Agency for International Development (NORAD), SAREC (Sweden), Swiss Development Cooperation

\section{References}

1. Levine MM. Escherichia coli that cause diarrhea: enterotoxigenic, enteropathogenic, enteroinvasive, enterohemorrhagic, and enteroadherent. $J$ Infect Dis 1987; 155: 377 389.

2. Levine MM, Edelman R. Enteropathogenic Escherichia coli of classic serotypes associated with infant diarrhea: epidemiology and pathogenesis. Epidemiol Rev 1984; 6: 31-51.

3. Mathewson JJ, Johnson PC, DuPont HL et al. A newly recognized cause of travelers' diarrhea: enteroadherent Escherichia coli. J Infect Dis 1985; 151 : 471-475.

4. Dean AG, Ching YC, Williams RG, Harden LB. Test for Escherichia coli enterotoxin using infant mice: application in a study of diarrhea in children in Honolulu. $J$ Infect Dis $1972 ; 125: 407-411$

5. Sack DA, Sack RB. Test for enterotoxigenic Escherichia coli using Y1 adrenal cells in miniculture. Infect Immun 1975; 11: $334-336$.

6. Gentry MK, Dalrymple JM. Quantitative microtiter cytotoxicity assay for shigella toxin. J Clin Microbiol 1980; 12: $361-366$.

7. Cravioto A, Gross RJ, Scotland SM, Rowe B. An adhesive factor found in strains of Escherichia coli belonging to the traditional infantile enteropathogenic serotypes. Curr Microbiol 1979; 3: 95-99.

8. Scaletsky ICA, Silva MLM, Trabulsi LR. Distinctive patterns of adherence of enteropathogenic Escherichia coli to HeLa cells. Infect Immun 1984; 45 : 534-536.

9. Handl C, Ronnberg B, Nilsson B, Olsson E, Johnsson H, Flock JI. Enzyme-linked immunosorbent assay for Escherichia coli heat-stable enterotoxin type II. J Clin Microbiol 1988; 26: $1555-1560$.

10. Svennerholm A, Holmgren J. Identification of Escherichia coli heat-labile enterotoxin by means of a ganglioside immunosorbent assay (GM-1 ELISA) procedure. Curr Microbiol $1978 ; 1: 19-23$

11. Moseley SL, Echeverria P, Seriwatana J et al. Identification of enterotoxigenic Escherichia coli by colony hybridization using three enterotoxin gene probes. J Infect Dis 1982; 145 : 863-869.

12. Boileau CR, d'Hauteville HM, Sansonetti, PJ. DNA hybridization technique to detect Shigella species and enteroinvasive Escherichia coli. J Clin Microbiol 1984; 20: 959-961.

13. Newland JW, Neill RJ. DNA probes for Shiga-like toxins I and II and for toxin-converting bacteriophages. $J$ Clin Microbiol 1988; 26: 1292-1297.

14. Nataro JP, Baldini MM, Kaper JB, Black RE, Bravo N, Levine $M M$. Detection of an adherence factor of enteropathogenic Escherichia coli with a DNA probe. $J$ Infect Dis 1985; 152 : 560-565.

15. Moseley SL, Clausen CR, Smith AL. A new bacterial adhesin
(SDC), United Kingdom, United Nation Development Programme (UNDP), United Nations Children's Fund (UNICEF); United Nations Capital Development Fund (UNCDF), United States Agency for International Development (USAID), World Health Organization (WHO) and World University Service of Canada (WUSC).

We thank Professor M. M. Levine, Center for Vaccine Development, Baltimore, MD, USA, for the DNA probes and the control strains, and P. Sukul for his secretarial assistance.

associated with enteritis in infants. Abstracts of the 25th Interscience Conference on Antimicrobial Agents and Chemotherapy, American Society for Microbiology, Washington DC. 1985, abstract no. 1128

16. Bilge SS, Clausen CR, Lau W, Moseley SL. Molecular characterization of a fimbrial adhesin, F1845, mediating diffuse adherence of diarrhea-associated Escherichia coli to HEp-2 cells. J Bacteriol 1989; 171: 4281-4289.

17. Baudry B, Savarino SJ, Vial P, Kaper JB, Levine MM. A sensitive and specific DNA probe to identify enteroaggregative Escherichia coli, a recently discovered diarrheal pathogen. $J$ Infect Dis 1990; 161: 1249-1251.

18. Echeverria $P$, Taylor $D N$, Seriwatana $J$ et al. A comparative study of enterotoxin gene probes and tests for toxin production to detect enterotoxigenic Escherichia coli. J Infect Dis 1986; 153: 255-260.

19. Stoll BJ, Glass RI, Huq MI, Khan MU, Holt JE, Banu H Surveillance of patients attending a diarrhoeal disease hospital in Bangladesh. Br Med J 1982; 285: 1185-1188.

20. Moseley SL, Hardy JW, Huq MI, Echeverria P, Falkow S. Isolation and nucleotide sequence determination of a gene encoding a heat-stable enterotoxin of Escherichia coli. Infect Immun 1983; 39: 1167-1174.

21. So $\mathbf{M}$, McCarthy $B$. Nucleotide sequence of the bacterial transposon Tn 1681 encoding a heat-stable (ST) toxin and its identification in enterotoxigenic Escherichia coli strains Proc Natl Acad Sci USA 1980; 77: 4011-4015.

22. Gicquelais KG, Baldini MM, Martinez J et al. Practical and economical method for using biotinylated DNA probes with bacterial colony blots to identify diarrhea-causing Escherichia coli. J Clin Microbiol 1990; 28: 2485-2490.

23. Feinberg AP, Volgelstein B. A technique for radio-labeling DNA restriction endonuclease fragments to high specific activity. Anal Biochem 1984; 137: 266-267.

24. Echeverria P, Taylor DN, Seriwatana J, Brown JE, Lexomboon U. Examination of colonies and stool blots for detection of enteropathogens by DNA hybridization with eight DNA probes. J Clin Microbiol 1989; 27; 331-334.

25. Maniatis T. Molecular cloning: a laboratory manual. Cold Spring Harbor, NY, Cold Spring Harbor Laboratory. 1982: 109-112.

26. Nataro JP, Kaper JB, Robins-Browne R, Prado V, Vial PA Levine MM. Patterns of adherence of diarrheagenic Escherichia coli to HEp-2 cells. Pediatr Infect Dis $J 1987 ; 6$ 829-831.

27. Echeverria P, Taylor DN, Seriwatana J, Moe C. Comparative study of synthetic oligonucleotide and cloned polynucleotide enterotoxin gene probes to identify enterotoxigenic Escherichia coli. J Clin Microbiol 1987; 25: 106-109.

28. Mathewson JJ, Johnson PC, DuPont HL, Satterwhite TK, Winsor DK. Pathogenicity of enteroadherent Escherichia coli in adult volunteers. $J$ Infect Dis 1986; 154: 524-527. 